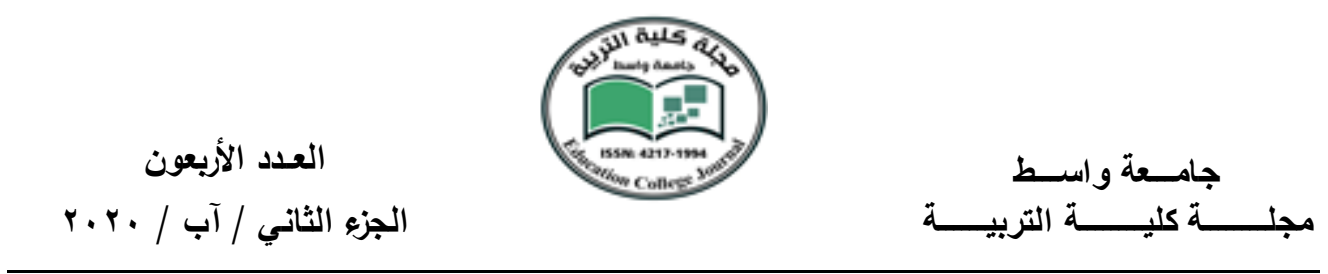

\title{
الوصف القصصي في شعر الأعشى الكبير
}

م. د. جنان عبد الله يونس الزبيدي

كلية الآداب/ جامعة الموصل

Janan.a.y@uomosul.edu.iq

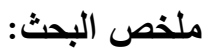

يعد الوصف تقنية أدبية لنقل الواقع من صورة مادية إلى صورة لغوية تعمل على تشكيل

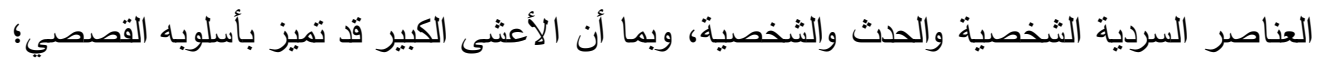
فجاء اهتمامه بالوصف لما له من قيمة في هذا التشكيل السردي وتحميله بالأفكار والمشاعر بلهربه والأحاسيس، لذا جاء هذا البحث لبدرس الوصف القصصي في شعر الأعشى الكبير. قام البحث على مدخل وثلاثة مباحث، تضمن الدخل تحديد مفهوم الوصف القصصي ، وخص

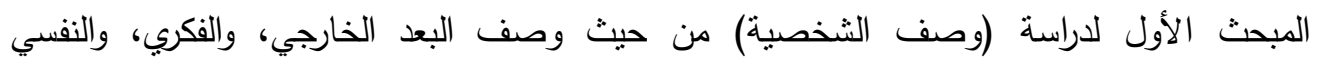
والاجتماعي، في حين تضمن المبحث الثاني دراسة (وصف الحدث) من حيث الاستهلال الوصفي والخاتمة الوصفية للحدث، وجاء المبحث الثالث لدراسة (وصف المكان) من حيث وصف المكان الأليف/ المكان المعادي، والمكان الطبيعي/ المكان الصناعي، ووصف المكان المفتوح/ المكان

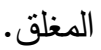

اعتمد البحث دراسة تحليلية للنصوص الوصفية لبيان قيمتها الفنية والجمالية على مستوى الثخصية والحثث والمكان مع بيان مضامينها في نماذج مختارة من نصوص الأعشى الكبير .

الكلمات المفتاحية: النصوص الوصفية الاعشى الكبير دراسة فنية وجمالية 


\title{
The Story Description in poetry of Al- Aasha Al- Kabeer
}

\begin{abstract}
The description regards a literary technique for moving the reality from material image to linguistic image work to form the reciting elements for the character. Al- Aasha had distinguished with his novel style, had came his interesting with this kind of poetry.

The research consist of introduction and three themes, the introduction came to limit concept of the novel description, the first theme specify for study (the character description), the second theme had came to study the (event description), the third theme came to study the (place description), and end with a conclusion.
\end{abstract}

\section{مدخل إلى تصديد مفهوم الوصف القصصي:}

يعرف قدامة بن جعفر (ت VTrVه) الوصف بأنه: " ذكر الثيء كما فيه من الأحوال والهيئات، ولمسا

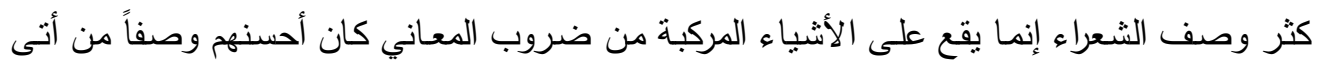

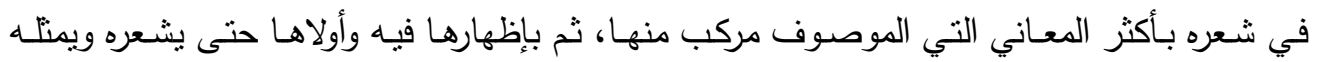

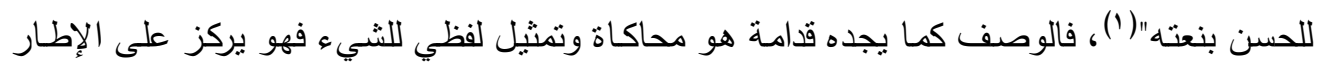

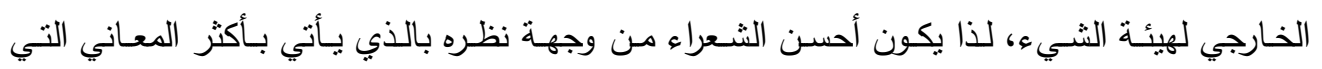

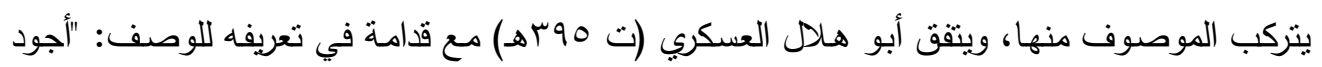

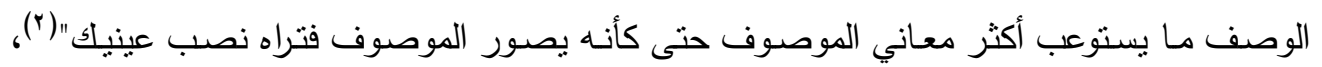
ويذكر ابن رشيق القيرواني (ت 07 ؛هـ) مفهوم الوصف في أقسام الثعر ، ويميز بينه وبين التشبيه:

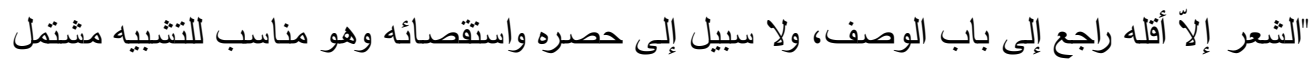
عليه، وليس بـه لأن كثير مـا يأتي في تضـاعيفه، والفرق بين الوصف والتشتبيه أنَّ هذا إخبار عن إنس

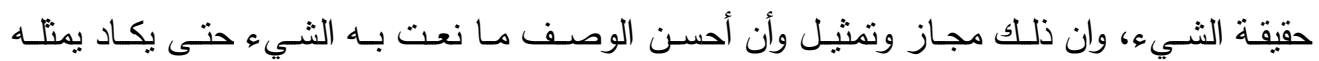

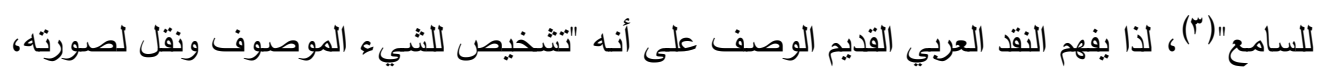
حتى يداخل السامع شعور بأنه مانل أمامه ليشاهده عينياً"( ). 
العدد الأربعون

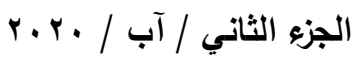

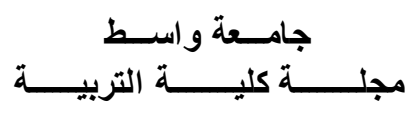

لقد مر الوصف بمراحل عديدة تطور فيها هي (•): ا - الوصـف النقلي: هـو الوصـف الذي يقف عند حدود المرئيـات والسـمعيات(")، إذ يقتصـر هـم الثـاعر على نقـل مـا موجـود في الطبيعـة مـن دون أن يرتقي بـالحواس والمظــاهر إلـى الفكـرة

الذهنية، لذا يبقى هذا الوصف نقلياً لأنه بطابق نسخة الكون (v). r - الوصف المـادي: هو وصف الظواهر الطبيعية والإحاطة بنواحيها والسمو إلى آفاقها، والوقوف على أسـرارها(^)، حتى تتيـر فينا المشـاعر والأحاسيس تحت تأثثر نفسـي بين فكرة في الذهن ومشهد في الحواس(9). (9) r - الوصف الوجداني: هو الوصف الذي يتخطى فيه حدود المظاهر ، فيتحول إلى وراء الأشياء أو حولها لإيجاد تفسير لللك، فينتقل المشهد من الحواس إلى النفس والضمير كان الثاعر يصف

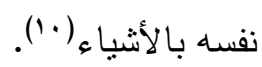
ويعرف الوصف القصصي في النقد الحديث بأنـه نسق من الرموز والقواعد تستعمل لتمثيل العبارات وتصوير الشخصيات أي مجموع العمليات التي يقوم بها الأديب لتأسيس رؤيته الفنية('")، إذ تتحدد غايـة الوصف في "أن يعكس الصسورة الخارجيـة لحسلٍ من الأحوال أو لهيئةٍِ من الهيئات فيحولها من صسورتها الماديـة القابعـة في العـالم الخـارجي إلى صسورة أدبيـة قوامها نسيج اللغـة وجمالهـا لتشـكيل الأسلوب"(rr)، ويعد الوصف القصصسي لوناً من ألوان التصوير إذ يتتاول ذكر الأشياء في مظهرهـا الحسي ويقدمها للعين (ri)، ويصور الناس والحيوانات والأمكنة والمناظر والأشياء والأمزجة النفسية

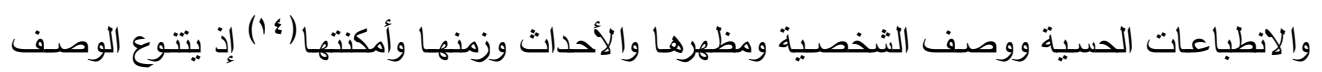
القصصي إلى نوعين هما(10):

1 - الوصف الحسي: هذا الوصف الذي يصدر عن وجود شيء مادي في الكون ينت بالرؤية الباعثة التي تتيح إمكانية رؤية الأشياء أو الشخصيات في الطبيعة، ويلتقط الأجزاء والصفات مباشرة ثم يحاول نرجمـة المرئي المصور بعدياً إلى لغـة، فتصبح هذه العملية مشروطة ببذل جهد بصري على الثيء الموصوف، ويتحول هذا الجهد إلى التأمل ثم يقتحم مجال الحكاية("1). r - الوصف المعنوي: هو الوصف الذي يتم تصويره في الذهن لأنه يصدر عن موقف فكري ينيب العلاقة بالمرجع، ويبني علاقة بين استمرار الفكرة أمام الذهن مع الصورة المتخيلة في الذهن، ثم

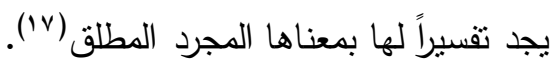


العدد الأريعون

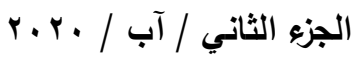

يقتضي الوصف القصصي عادة انقطاعاً في السيرورة الزمنية، "إذ إن الراوي عندما يشرع في الوصف

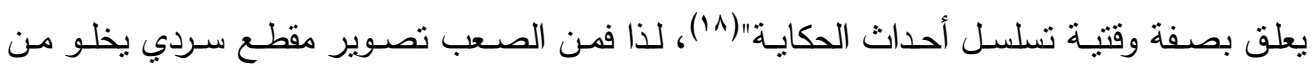

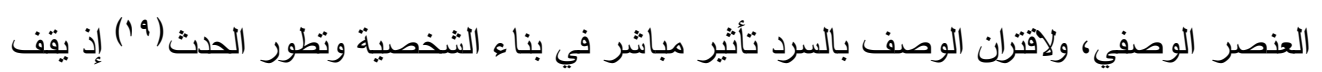

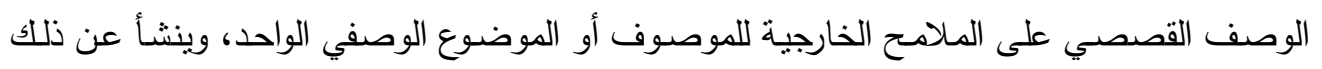

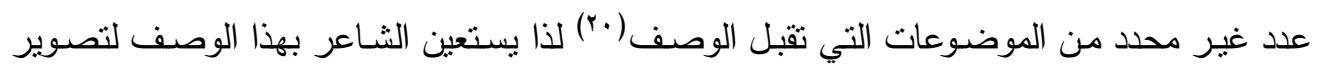

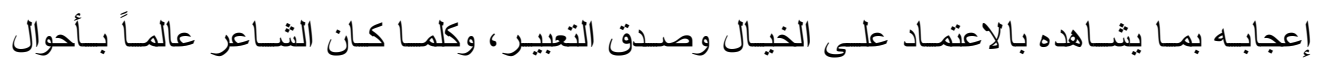

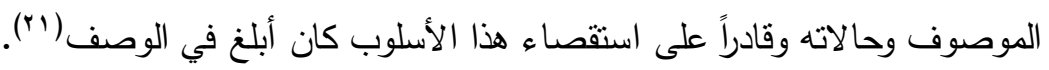

المبحث الأول: وصف الثخصية: بعمل الوصف القصصي على الكثف عن خفايا النص السردي ومكونـات الشخصية(rr) إذ يعدل

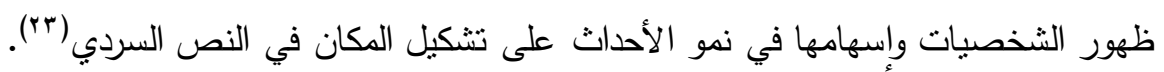
1 - وصف البع الخارجي:

يعد وصف الملامح الخارجية للثخصية أمراً مههاً فهو أحد الأركان الأساسية للتشخيص وهو نقديم

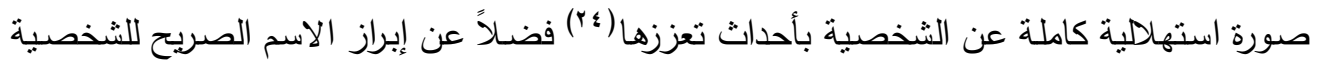

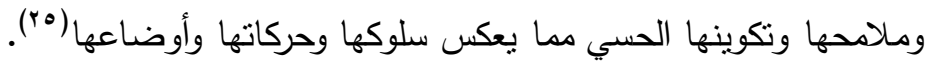
ومن أمنلة الوصف الخارجي للثخصية:

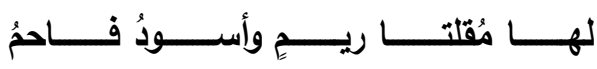

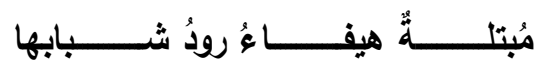

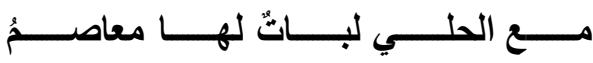

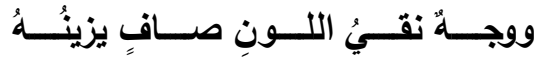

(r) لهُ متَ بوانٍ نبت ذرى أقد

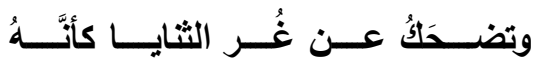

يعمل الشـاعر في وصفه القصصي على منح صـاحبته (هريرة) بأوصساف متعددة تدل في

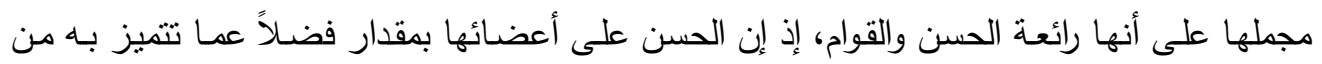

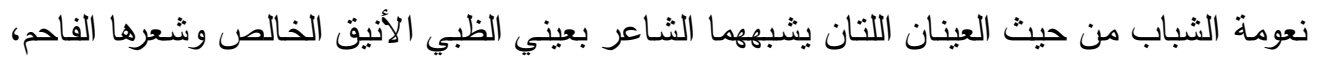


العدد الأربعون

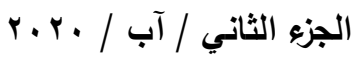

وينتقل إلى وصف وجهها بكونه نقي اللون، فضلاًا عن الصدر والمعاصم الكسوين بالحلي، ولا يكتفي الثـاعر بهذا الوصف عند هذا الحد بل يكمل البعد الخارجي لصـاحبته من حيث ضحكها وملامـح

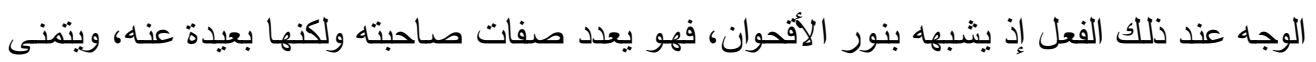

الظفر بها.

ومن نماذج وصف البعد الخارجي للشخصية:

عــــى أن فــــي الطـــرفِ منهــــا فتـــورا

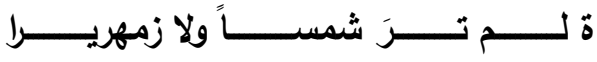

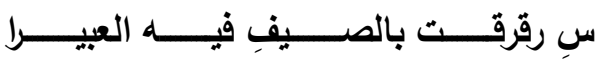

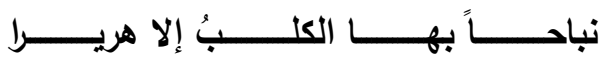

وتـــــــبطنُ مــــــنـن دونِ ذاكَّ الحريــــــــا

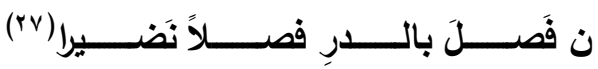

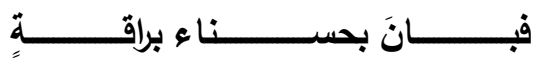

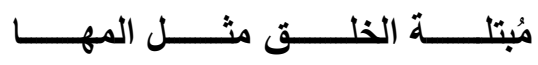
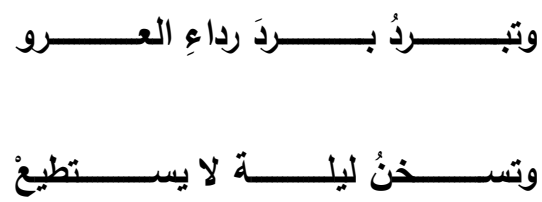

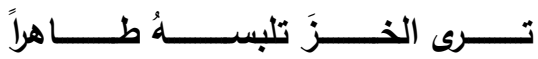

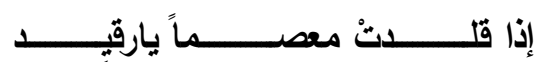

يركز الثـاعر في وصفه القصصي على ذكر أوصـاف صـاحبته إذ يمكن تلخيص دالاتها بالحسن البراق، إذ يصف تناسق أعضـاء جسمها ببقرة الوحش، ويوحي بنعومة عيشها، إذ لا تلدغغها ريـاح

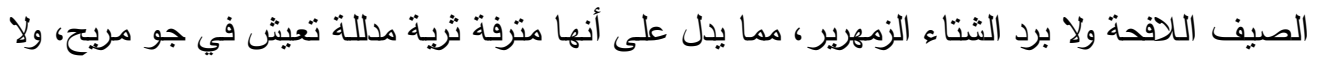

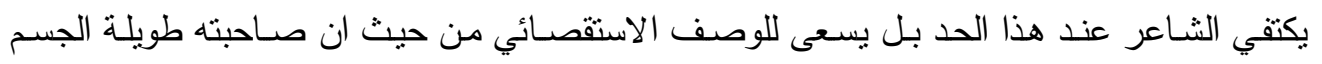
وعبقة الرائحة ويشبهها بالعروس التي نثرت عليها العطور فضلاً عن ثنابها من الخز والحرير. ץ - وصف البعد الفكري: يعد وصف البعد الفكري للثخصية من أهم أبعادها لذا يكون تحديده أمراً أساساً للكثف عن الأحكام

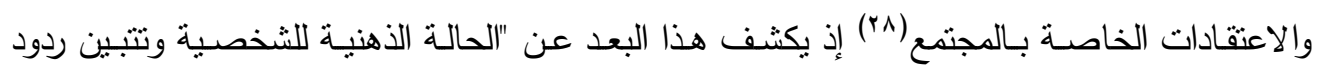
أفعالها كما أنها الوسيلة الرئيسة لصباغة الثخصية المفعمة بالحياة"(rar). 


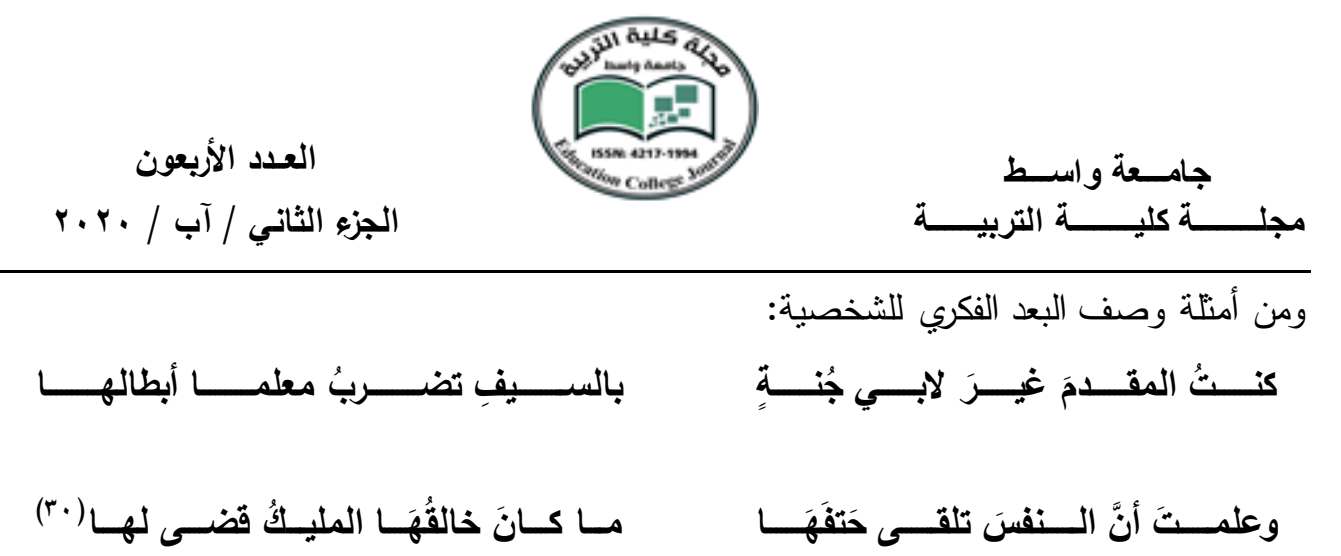

يقلم الثـاعر وصفاً لشخصيته فيما بسمى بالوصف الذاتي من حيث بعده الفكري إذ يجد أن الكتيبـة التي ترد نفسها بالحديد تكون كتيبـة خضـراء من حيث المنظر يخشى منها العدو، ويعد نفسـه المقدم لأنه بلا وقاية بل لانَّ سلاحه السيف مما بدل على استبساله وشجاعته الفائقة. ولا يرتدي الترس الذي يخفي ويستر جسد المقاتل مما يذل على إيمانه بالطعن والجراح لينتقل الشاعر إلى وصف وجهة نظره الإيمانية فيما يتعلق بالموت الذي يقع على النفس الإنسانية بقضاء الله تعالى وقدره. ومن نماذج وصف البعد الفكري للشخصية:

وأصـــبحتَ بعــــ الجـــور فــيهن قاصـــــا

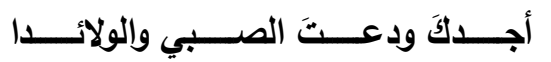

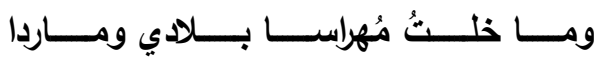
ومـــا خلــتُ أن ابتـــاع جهــلاً بحكمــة

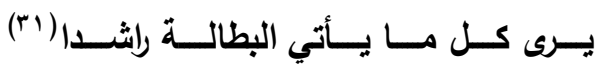

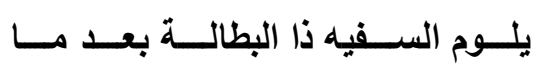

إذ كان الثـاعر يصف بعده الفكري في النص الأول فهو يعـل على تقديم الأوصـاف التي تتعلق بالبعد الفكري لممدوحه من وجهة نظره الخاصة، إذ يصف بالجد في أعلى صورة من حيث القصد بعد

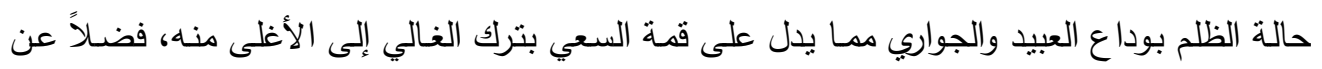
وصفه بالحلم ضد السفه الذي ينشأ بالنظر إلى الفساد لأنه أعلى درجات الرشاد للتخلص من المظالم

$$
\text { والفساد والضياع والخسران. }
$$

يتمنل وصف البعد النفسي للشخصية في "الاستعداد والسلوك والرغبات والآمال والعزبمة والفكر وكفاية الشخصية بالنسبة لهدفها ويتبع ذلك المزاج من انفعال وهدوء ومن انطواء أو انبساط"(بّ). لذا يبدو هذا الوصف بالأفكار والدوافع والاتصالات والميول والاتجاهات والقدرات والظواهر المتشابهة(ب). 


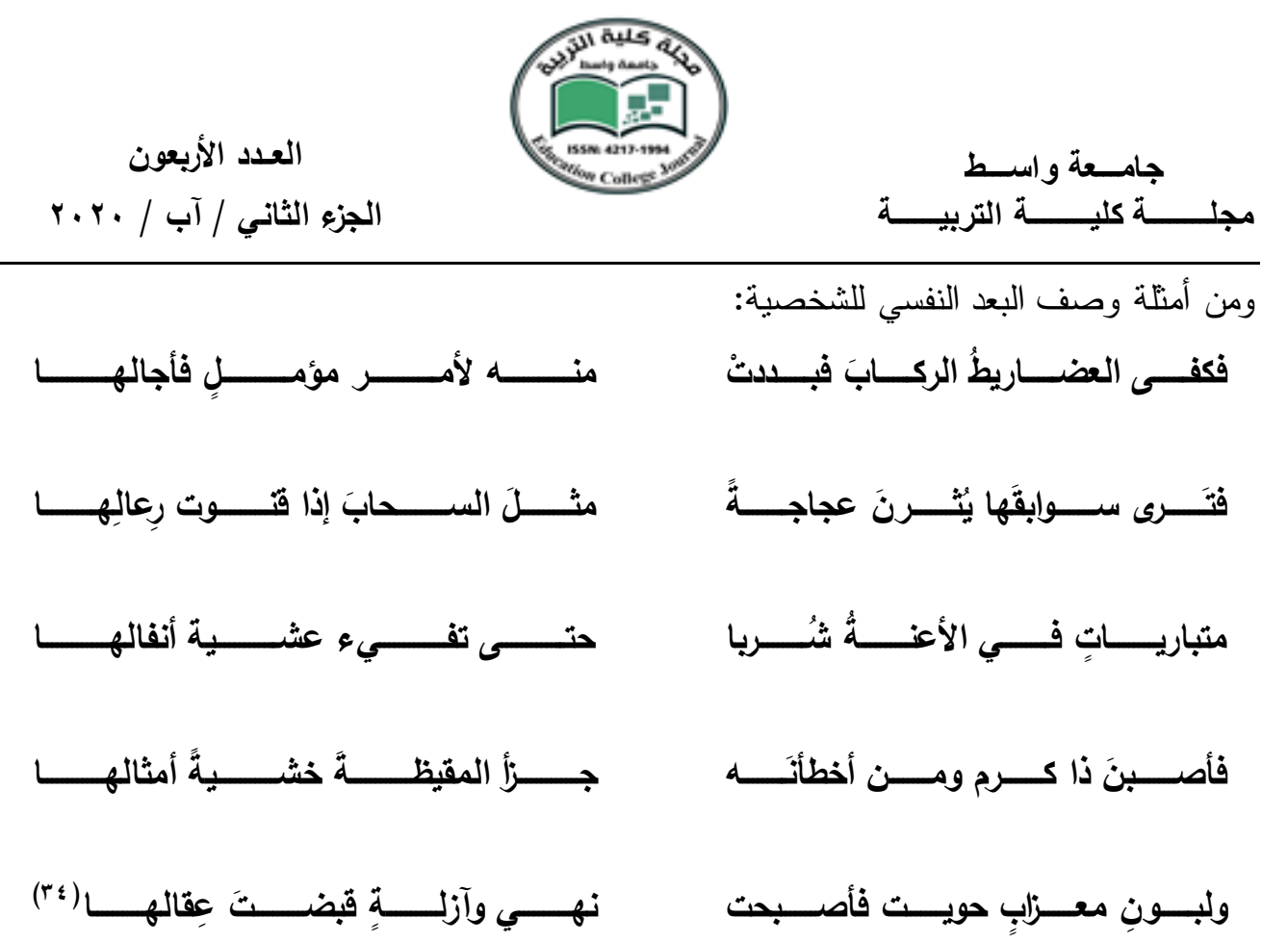

يصور الثـاعر البعد النفسي لمدوحـه وفرسـانه والنـاس من حولـه إذ يمسـك الخدم بالركـاب ويركب الفرسان بانتظار إثـارة من الممدوح للهجوم، مما يبدو هنا البعد النفسي إذ ينطلق الفرسان في مهتهم ليعودوا بالغنائم والأسـاب، ويوحي الثـاعر بالعنـاء والتعب الذي يحل بهؤلاء الفرسـان من الانطـلاق للغزو، وينتقل الثاعر ليقدم البعد النفسي لشخصيات الناس من حيث خوفهم على المدوح من إصـابة العدو إذ تزال النعمة وحالة الرعب والفزع من الغزو والغارة ليلحق ذلك المعاناة التي تكون على الناس كلهم في أوقات الغزو. ومن نماذج وصف البعد النفسي للشخصية:

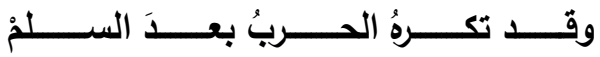

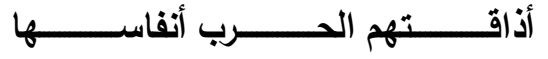

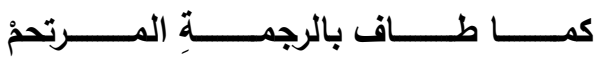

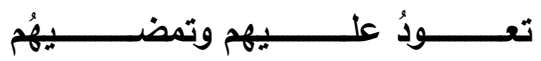

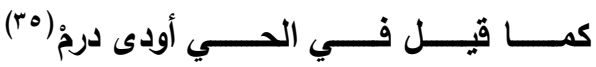

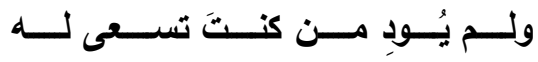
يسعى الشـاعر لتصوير البعد النفسي لأفراد بني عامر من حيث دالات الفزع والرعب من الحرب التي لفحتهم أنفاسـها الكريهة، وعن عدم الثـعور بـالأمن والسـلام من معاودة الحرب، وتحمل مشـاقها ولابد 
العدد الأريعون

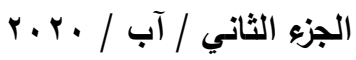

من الوصول إلى حالة من الأمسان لضرب الثمل الجار الذي لا يكون بحالة هادئة إلاّ بعد أن يصل

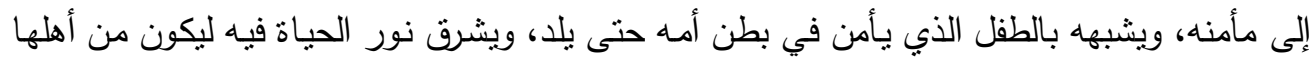

ويتحمل مشاقها.

\section{؛ - وصف البعد الاجتماعي:}

يمكن أن يقدم الوصف القصصي شرحاً بوظيفة النص وقدرته على التعبير عن الواقع ويكثف عن

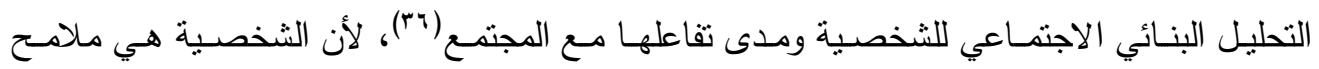

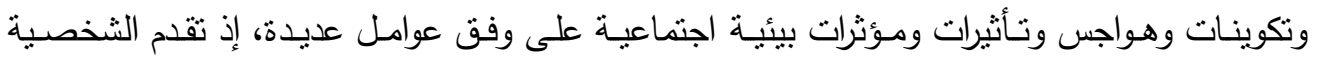

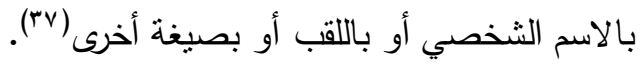
ومن أمتلة وصف البعد الاجتماعي للشخصية:

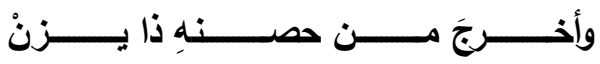
Sis عة أنالًَ أُذين

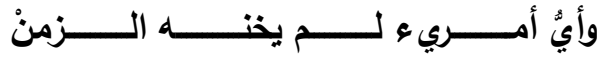

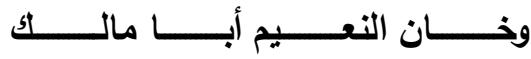

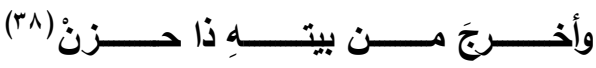
افــــــــاد الملــــــــــوكَ فأفنْ

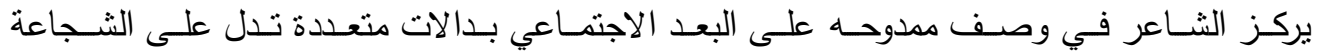

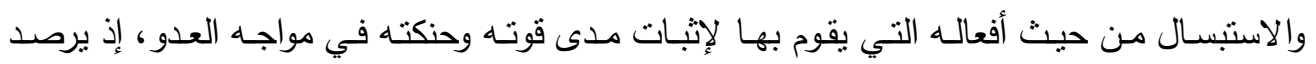

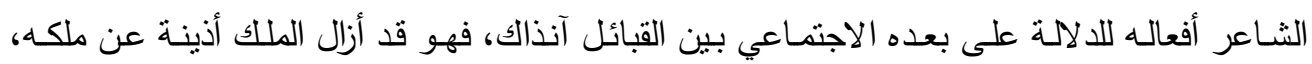
فضلاً عن إخراجه لذي يزن من الحصون وهو المعروف بإهلالك الملوك وإخراج الناس عن مسنترهم في دار الثيخوخة. لذا يعمل الثاعر على تقديم أوصاف معرفية للممدوح في ذللك الزمن. ومن نماذج وصف البعد الاجتماعي للشخصية: 
العدد الأريعون

الجزء الثاني / آب / • • • الإعون

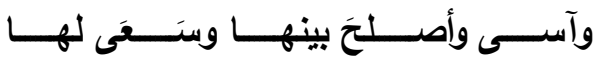

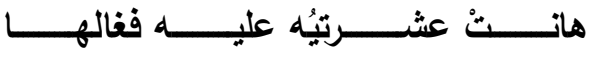

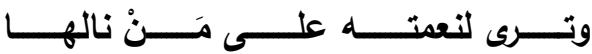

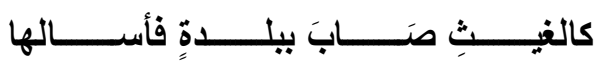

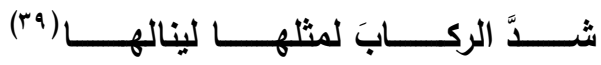

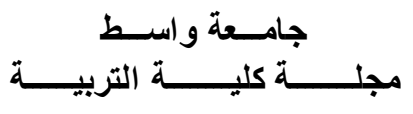

جامسـعة واســط

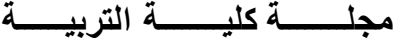

وأهـــــانَ صـــــالحَ مالــــــهِ لفقِ

مــا إن تغــبُ لهـا كمــا غــابَ امــرؤ

وتَـــرى لــــه ضـــــاً علــــى أعدائــــهـه

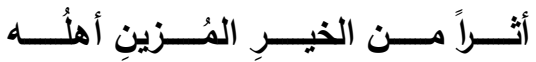

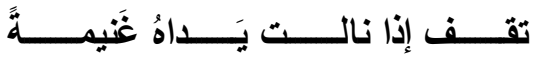

يصف الثاعر البعد الاجتماعي لشخصية ممدوحه بدالات متعددة من حيث انه يهب ماله للفقراء من قومه، ويعمل على مواسـاتهم والإصـلاح بينهم، فضـلاً عن السعي دوماً لما فيـه خيرهم وهم على باله في كل وقت وحين، وعدم الإضرار بهم فضلاً عن معرفته بأمور الحرب وسياستها أحب القتال وألفه، وهو يتابع دوماً بحسب الغنائُ الواحدة للو الأخرى ليصل بها رحمه من ذوي القرابة أفضل من وجودها عند ذي النعمة. المبحث الثاني: وصف الحدث: يقدم الحدث رصداً للوقائع التي يقتضي تلاحمها وتتابعها إلى تشكيل مادة حكائية تقوم على جملة من العناصـر الفنيـة والتقنيـة والألسـنية معـاً( •؛) إذ يـأتي الوصف القصصـي ليكون أداة لتشـيبد الحدث وتقديمه وتطويره ونموه( (1). 1 - الاستهلال الوصفي للحدث: لقد تتبه النقـاد العرب القدامى إلى أهميـة الاستهال وتحدثوا عن براعته الذي ينطـي على وظـائف نفسية مؤثرة في نجاح النص بنائياً وتوصيلياً( (؟) إذ يجري تحديد الاستهلال "بناءً على تكامل فكرة البدايـة واسـتقرارها على وفـق أنمـوذج بنـائي ودلالـي يتـوفر على قدر مـن الاسـقاللية في التعبيـر والتجديد"(ז٪)، إذ يتأرجح معنى الوصف في الاستهلال بين مستوبين اثنين هما: الإبانة عن الهيئات والإخبار عن الموصوفات(؛ ؛). ويعد الاستهلا الوصفي إحدى آليات السرد فهو يعزز حضور هذه الآلية ويسهل الدخول إلى المنن النصي ويضفي قدراً عالياً من تصوير الشخصية والفضاء(ه؛.). 


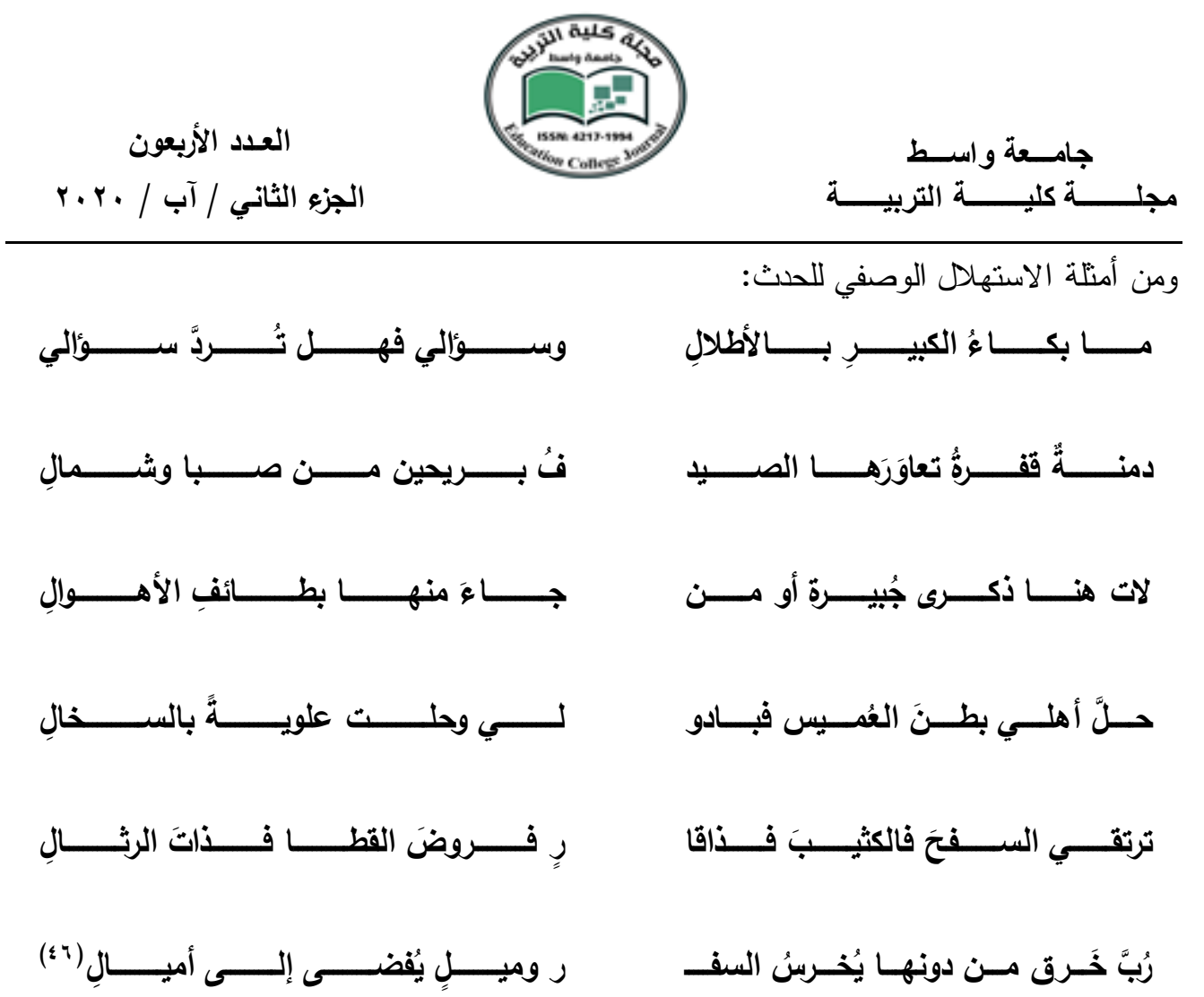

يدخلنا الثـاعر عالمه باسـتهلال يقدم فيه دلالات وصفية من حيث ذكر الأطـله وأثرهـا في النفس ويتساءل عن وقوف الرجل الكبير الذي يبكي، ويسأل الأطلال فهو يعلم أن الدمنة المقرة قد بعثت فيها ربـاح الصيف فيـه لا ترد السؤال وبهذا يقدم الشـاعر وصفاً للحدث من حيث فعل الريـاح على الدمنـة مـن الجهات كلها ،ثم يضـيف الذكرى ومقام جبيرة أو الرسول وليصف دالـة البعد من حيث مكانه ومكان الحبيبـة إذ ارتحل قومها شـالاً إلى السخال في حين أنـه مـن بطن العميس، إذ يرتب أحداثه بالفعل للالالـة على الحبيبـة بـ (السفح) و (الكثيب) و (ذاقـار) و (روض القطا) و (ذات الرثنال) للإيحاء بالبعد عنها من حيث القفار التي لابـد أن يكابدها المسافر للوصـول إليها بسفر طويل فيـه المتاعب والمصائب لأن السير في أعقاب الليالي والشمس الملتهبة مع تتوع المساحات الأرضية التي يطالها السفر بين الاستواء والرمـال ومـا إلى ذلك. لذا يعمل الاستهال الوصفي للحدث على تقديم الحدثثن الواقعي والمتخيل للوصول إلى ديار الحبيبة الذي يقف عائقاً أمام رؤيتها والظفر بها. 

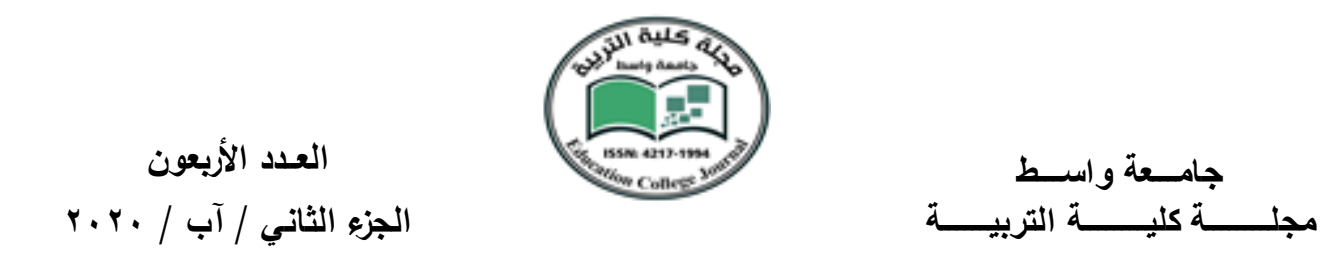

ومن نماذج الاستههل الوصفي للحدث:

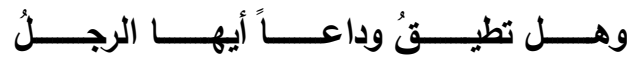

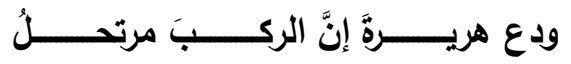

تمشـي الهــوينى كمــا يمشــي الـوجى الوحـلُ

غــــراءُ فرعــــاءُ مصــــولْ عوارضـــــها

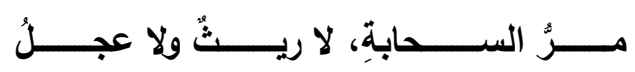

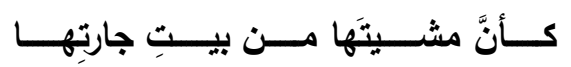

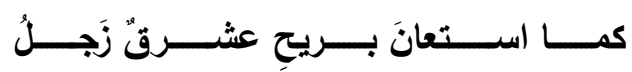

تســـعُ للحلــي وسنواســـاً إذا انصــرفت

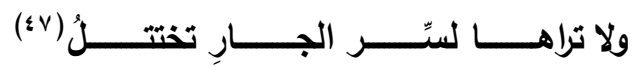

لَيســـت كََــنْ يكـــرهُ الجيـــانُ طلعتَهــــا

يستتد الثـاعر في استهال الحدث على وصف وداع صساحبته (هربرة) ويقدم دالات وصفية لتهيؤ الركب للرحيـل، ومجيء الـوداع بعده بعلاقة سـبيية يقوم عليها الحدث السـردي، ثم يرتب الثـاعر أوصاف الحدث بالتتابع وتأتي بعد انتهاء الرحيل والوداع مرحلة الضعف الذي يدركه، فما يلبـث أن يخاطب نفسـه بوصف حدث عدم الاسـنطاعة على الوداع، ثـم ينتقل الثـاعر إلى وصـف خيـال الصـاحبة، وهـو يتمثل أمسام عينيـه على سبيل الحلث الاسـتباقي الذي يتمنـاه، فيعمل على تصـوير معالمها الجسمانية والرشـاقة، ليصل إلى وصف حركة فعلها بالسباحة في الفضـاء على تمهل شديد فضدلاً عن سماع صوت الحلي في معصميها كأنه شجرة مقدار ذراع قد عملت الريح على تحريكها. r - باتمة الوصفية للحدث: تعد الخاتمـة "الركن الأهم في تشكيل بنيـة النص الإبداعي، ولها وجودها ودورهـا في تحديد مسـارات العمل واتجاهاتـه"(^§)، إذ نتطوي الخاتمـة على أهميـة علاميـة وجماليـة تكاد توازي أهميـة الاستهلال

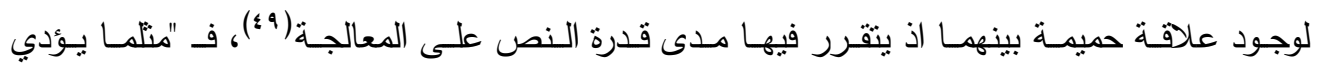
الاستهلال دوراً استراتيجياً حاسماً في التكوين النصي، لأنه منطقة انفتاح على الوصف وتحقيق الكون التخيلي، فإن الخاتمـة تقوم بدور معاكس إذ تعدل على غلق الفضـاء التخيلي وإنهاء سلسلة العمليات النصبة على مستوى الكتابة والتسجيل، وليس على مستوى القراءة والتأويل"( •(). 


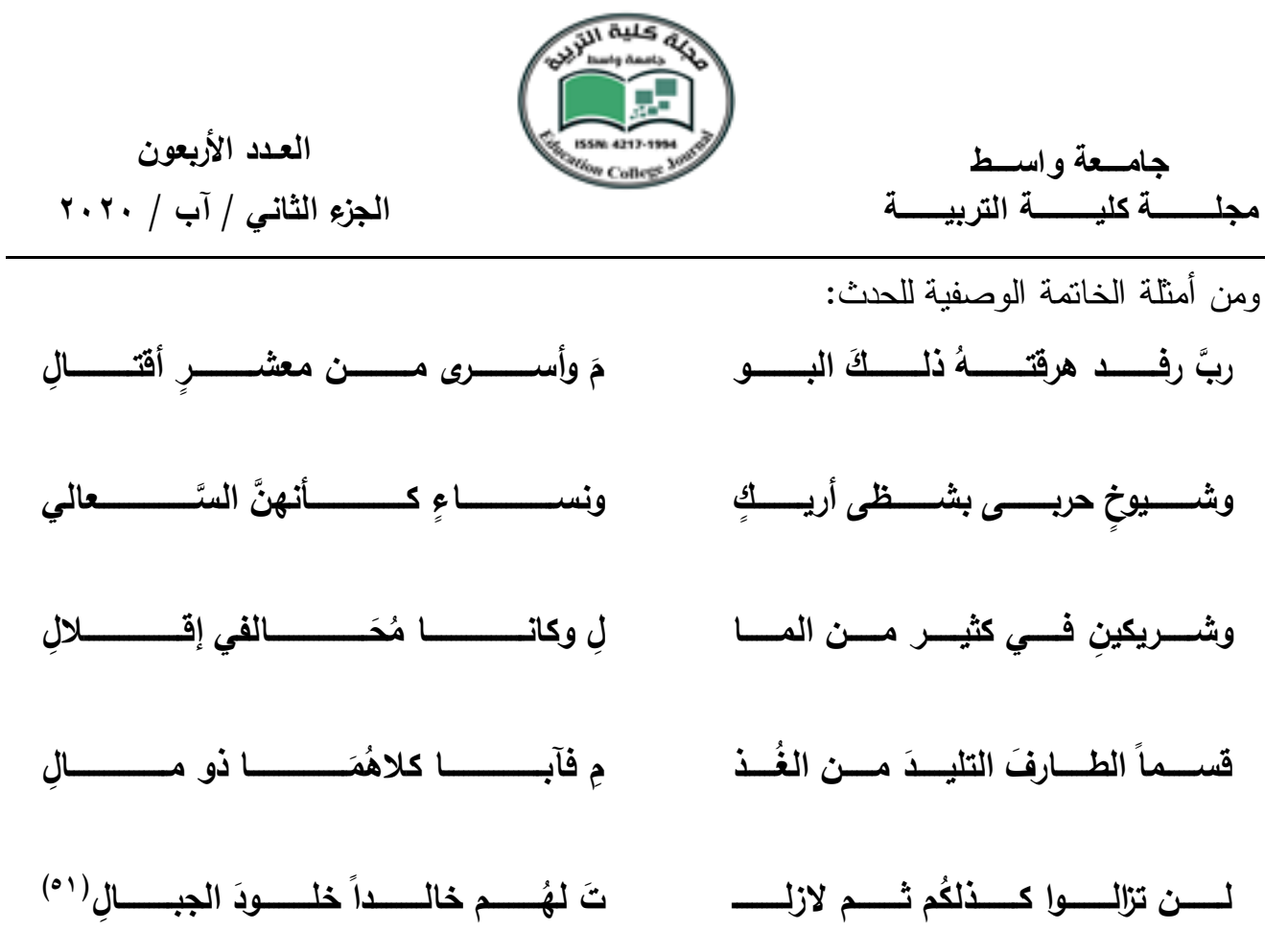

إذ كان الثـاعر قد استهل الحثث بدالات وصفية من حيث حدث البكاء على الأطلال والسؤال وفعل الريح بالدمنة، فهو يسعى في هذه الخاتمة إلى وصف حدث آخر ينهي به القصيدة هو حدث القتال للسؤال عن عدد الأسرى من جراء عملية القتال وأثزها في النساء الذي بشبهن بالسعالي من أثر الدذلة

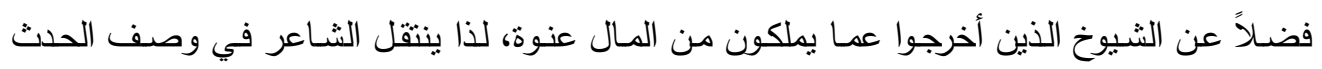
الاختتامي لينتقل إلى وصف الثريكين اللذين أصبحا من أثر القتال معدمين حليفي الفقر والإقلال، لئل

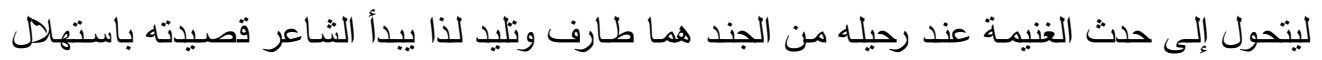
وصفي وينتهي به لتوضيح سير الحدث السردي بالدالات الوصفية.

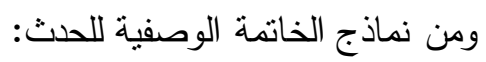

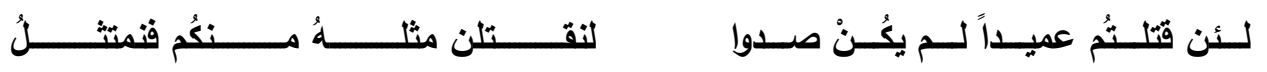

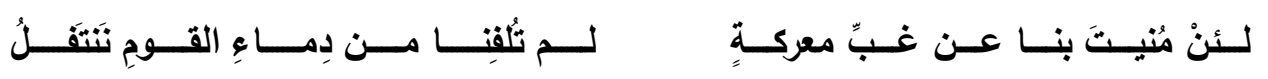

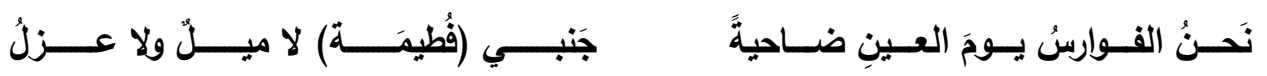

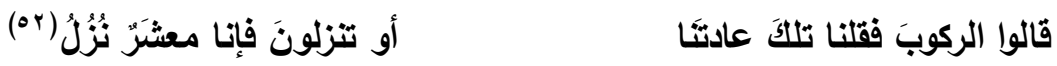


العدد الأربعون

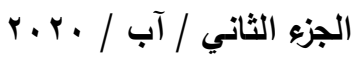

لقد بدأ الثاعر باستهلال وصفي للحدث من حيث وصف الرحبل والوداع وعدم الاستطاعة لتحمل هذا الموقف، وتخيل الحلث الاستباقي للقاء الحبيبة، لذا يعدد في خاتمة الحدث من القصيدة إلى تقديم دالات وصفية أخرى تكمل الحدث السابق عن القتال من حيث وصف لفئ حدث استباقي مقبل

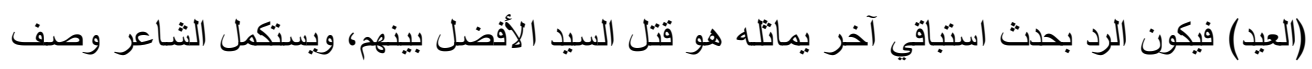

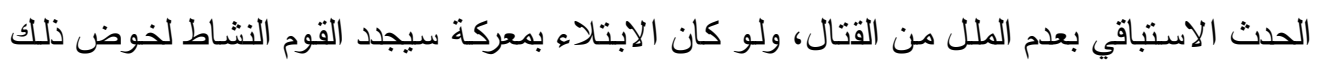
مرة أخرى، ويتحول الثاعر إلى وصف الحث الحاضر بعد أن يستوفي الحدث الاستباقي فيما يتعلق الانق بوصف فعل الحدث الذي يقوم به الفوارس على وفق الزمن الماضي فيما يتعلق بيوم العين الذي كان

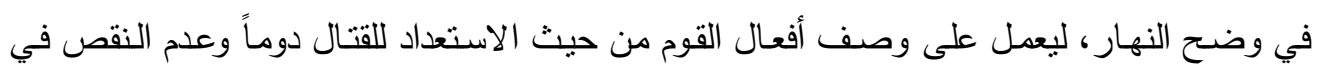

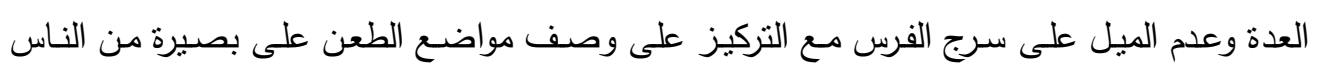
والحذق في إصابة الهذف.

المبحث الثالث: وصف المكان: - المان

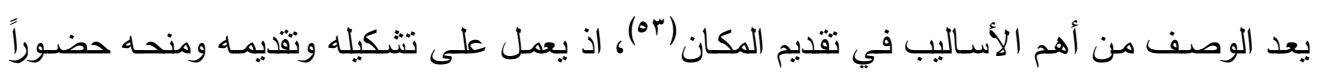

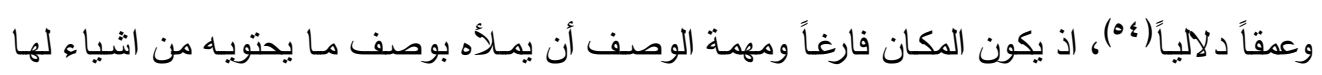

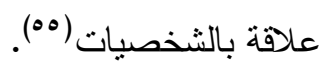

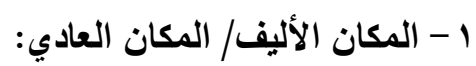
المكان الأليف هو "مكان العيشـة المقترنة بالدف والثـعور بأن ثــة حمايـة لهذا المكان من الخـارج

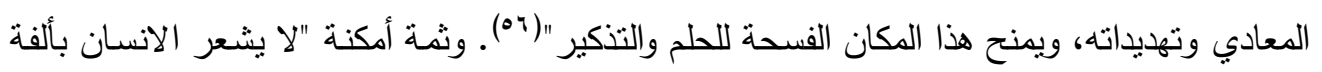

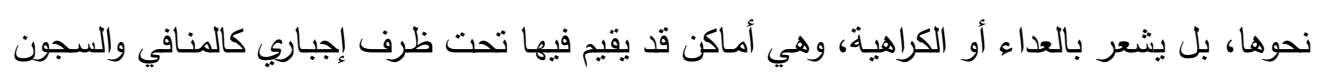

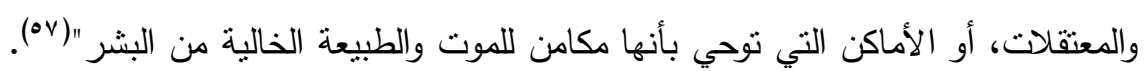
ومن أمنلة وصف المكان الأليف: 


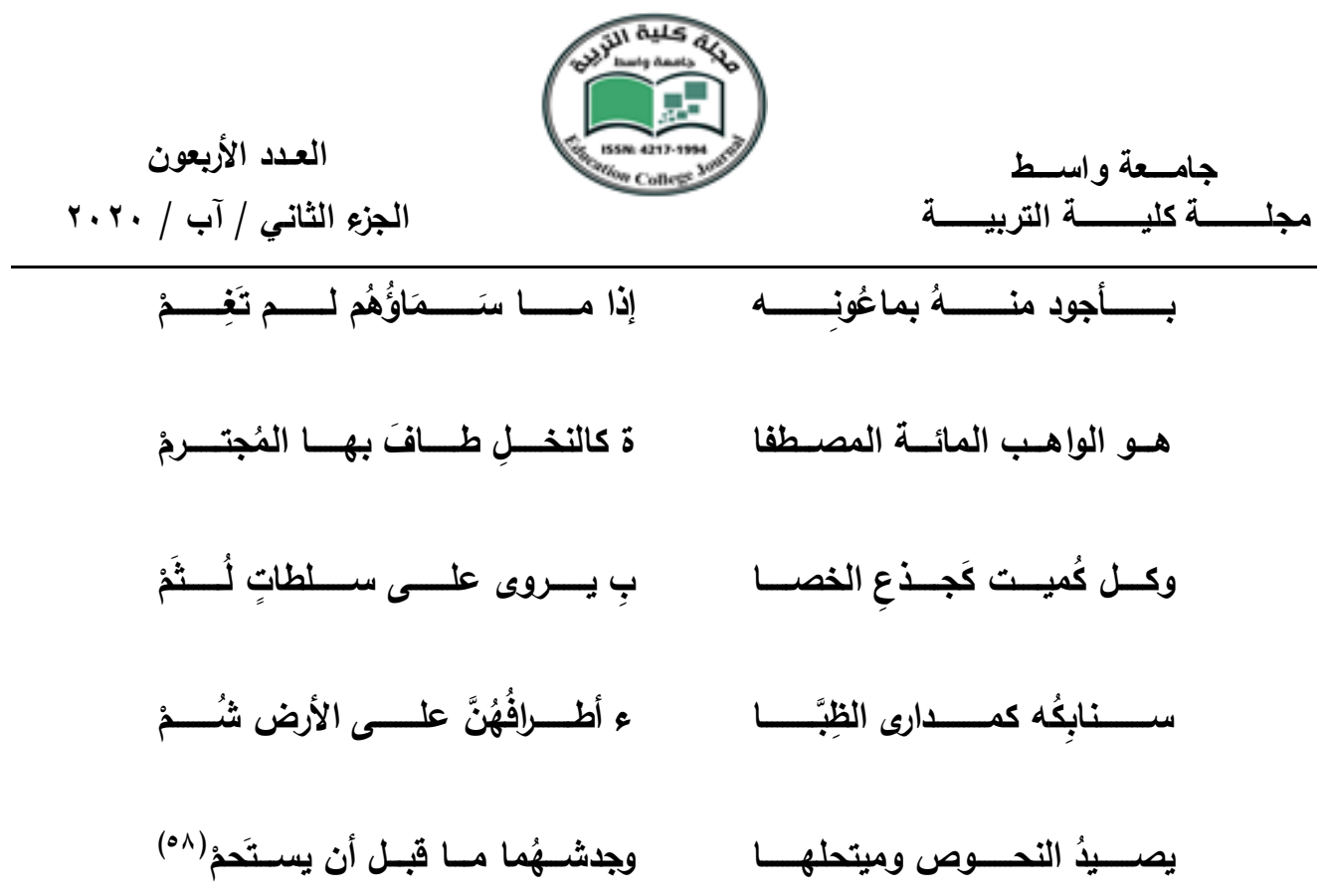

يعمل الثـاعر على وصف المكان الآليف من حيث تواجد المدوح في مكان مـا يعطيه من الابل اذ

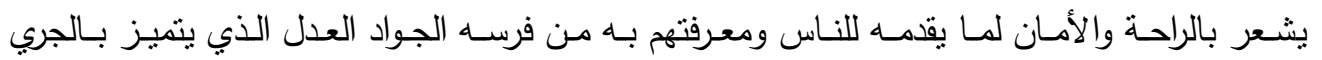

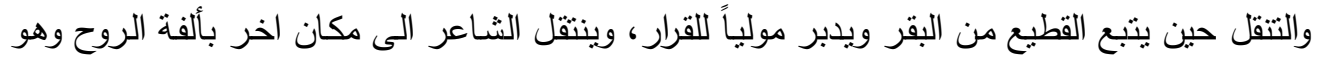
مكان الصيد الذي يجد فيـه منعته من حيث حركـة الفرس وتوجهه الذي يشبهه مفتـاح اللؤلؤ الذي تركي انقطع مسلكه فهو يتلو بعضه البعض الآخر . ومن نماذج وصف المكان الأليف:

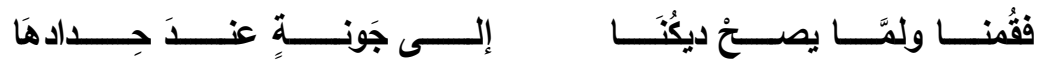

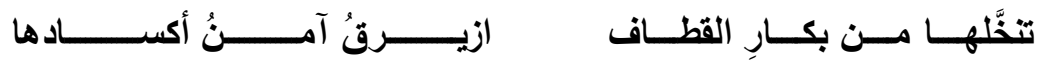

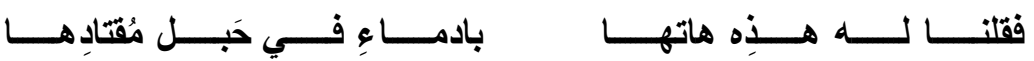

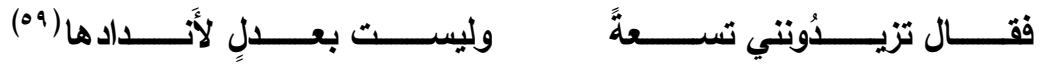

يستند الثـاعر في تقديم المكان الذي بألفه ويرتاح في المكوث عنده بدالات وصفية من حيث تحديد

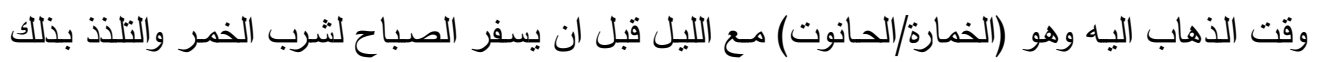


العدد الأربعون

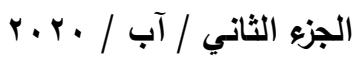

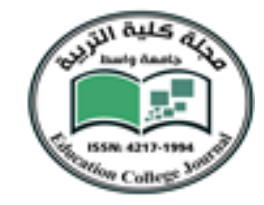

من خابية الخمر التي كانت تطلى بالقار ، ومن ثم الارتياح من الخمار الجميل الذي من العلوج وليس من العرب من حيث زرقة عينيه، ويعمل على مساومته على ثمنها الغالي ليشتربها. ومن امتلة وصف المكان المعادي:
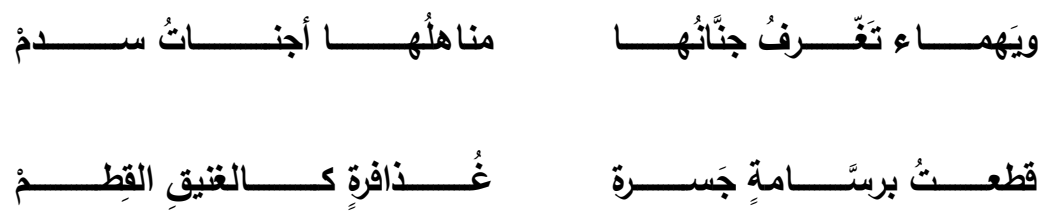

إذا مــــا ارتـــــى بالســـراب الاكـــْ

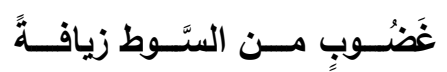

وكانَ

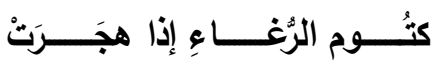

وإذا كان الثـاعر يصف أمكنة الألفة من حيث راحة مددوحه وراحته فهو يسعى في نصوص شعرية

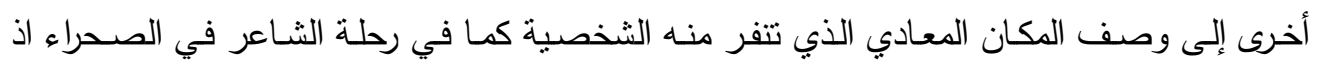
يصورها في رهبتها المفزعة وسكونها الذي يجعل السائر فيها يتملكه الخوف والرعب، لما تتسم به هذه الصحراء من عدم بيان طرق السير فيها أولاً لأنها راكدة لذا يشعر الأعشى بالعداء تجاه هذا الككان

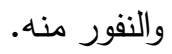
ومن نماذج وصف المكان المعادي: ويلدةٍ مثنل ظهر التُرسِِ مُوحشَة

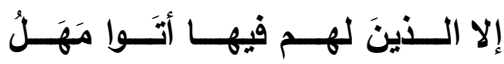
لا يتنمسى لهـا بــالقيظِ يَركبُهــا في مِرفقيها إذا استعرضتها قتلُْ (7) جاوزتهــا بطــــِحِ جَسـرةٍ سُــرُحِ يلقي الثشاعر بظلال وصف المكان المعادي بدالاته المتعدة على النفس من الثعور بالوحشّة في هذه البلدة الني شبهها بظهر الدرع في انبساطها وإنكارها، إذ لا شيء فوقها يسر النفس والقلب ليس فيها 
العدد الأربعون

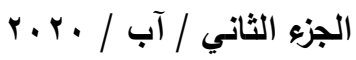

إلا صـوت الجن ولاسيما في الليل، لذا لابد مـن التخلص من هذه الرهبـة والفزع إلى العمل على مجاراتها والتخلص من مصاعبها بالناقة الجسرة التي تمنلك مواصفات تباعد الفتل عن زورها. ب - المكان الطبيعي/ المكان الصناعي: المكان الطبيعي هو المكان الذي لم تتنخل يد الإنسان في إقامته وتشكيله فهو قد وجد هكذا منذ الأزل بصورته الخاصة وخواصه المعبرة(r")، ويعد الدكان الطبيعي من أهم أجزاء البيئة، ويتمثل بالطبيعية ورموزهـا(با)، أمسا المكان الصناعي فهو المكان الذي يستحثث من الإنسان فكلما كان المكان مؤثراً

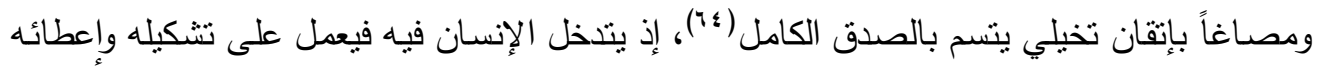
طابعاً مختلفاً عن غيره من الأمكنة(70). ومن أمنلة وصف المكان الطبيعي:

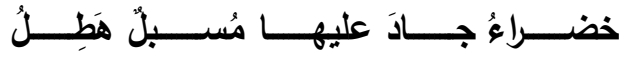

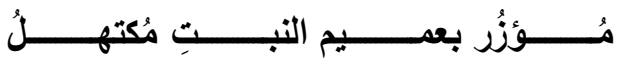

(71)

يفصل الثـاعر في تقديم دالات وصفية للمكان الطبيعي بانعكاس ظلامه على وصف الحبيبة التي

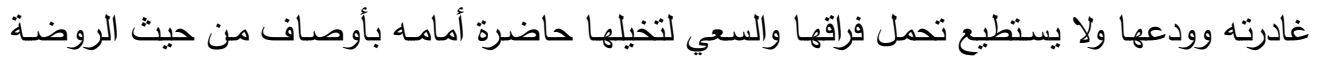

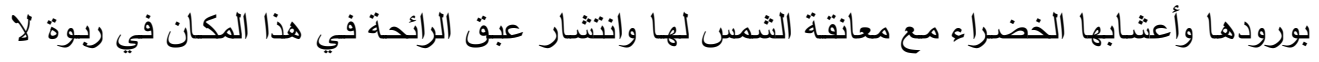

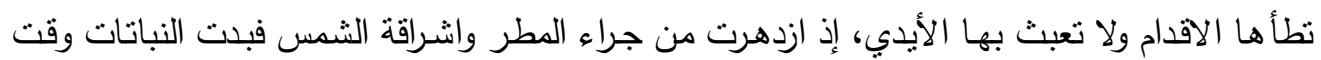

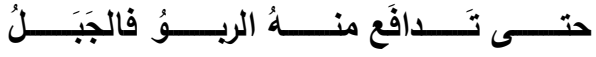

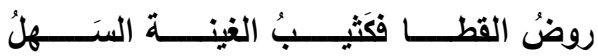

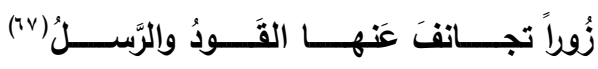
الغروب لنتشر من المكان ريح الورد. ومن نماذج وصف المكان الطبيعي:

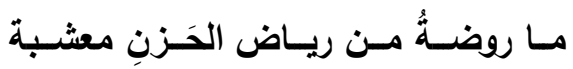

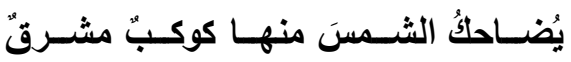
فالســــحُ يجـــري فخنزيـــر فبرقن

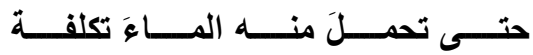
يسـقي ديساراً لهــا قــــ أصــبحَتْ عُرُبــاً 
العدد الأريعون

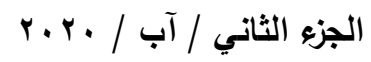

يستند الثـاعر في وصفه للمكان الطبيعي إلى دالات مكانية ويقدمها بالأوصاف التصويرية

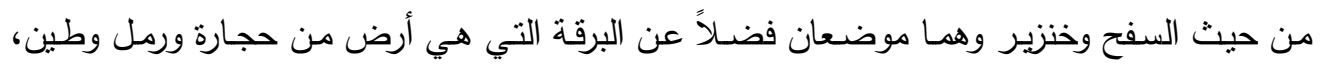
ومن ثم ينتقل الثـاعر الى الربو المرتفع من الأرض ليصل إلى الجبل إذ ينقدم الوصف لجن لجزئيسات

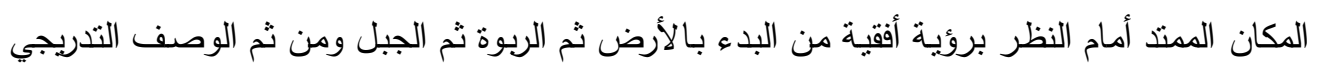
الذي يعمل على الرؤية العمودية في وصف الدالات المكانية من جريان الماء في الروض، لينتقل من لئن

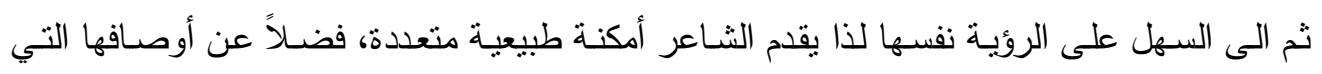
تتعلق بجغرافيتها في الكون من حيث الانخفاض والارتفاع. ومن أمنلة وصف المكان الصناعي:

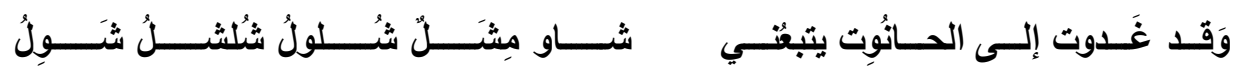

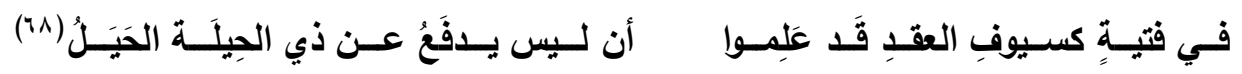

وإذا كان الثـاعر قد قدم دالات وصفية للمكان الطبيعي الذي لا تتدخل يد الإنسان في نتكيله فهو

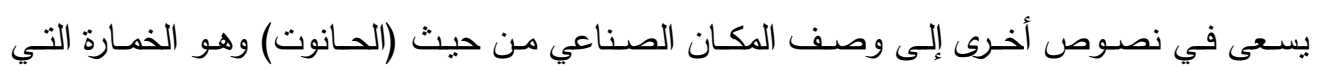
يقصدها الثاعر لثرب الخمر مـع رفقاء اللذة، مما يتطلب هذا المكان اعداد مجلس لرواده واستقبالهم ومن ثم توفير الأدوات التي تحتوي على الخمر كما في الخابية التي تعلق قلب الاعشى بها لثرائها

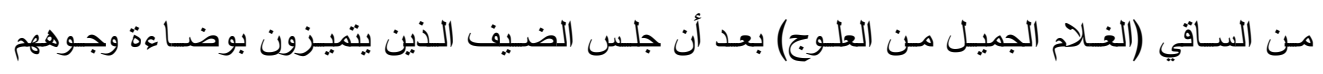
وينتظرون الساقي لأداء طلبات شربهم للخمر . ومن نماذج وصف المكان الصناعي:

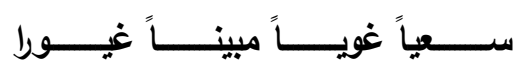

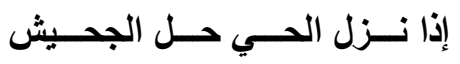

وغضـا مـن الطرف عنها وتسيرا(79)

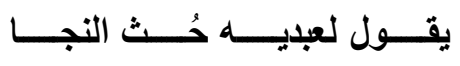

يعد الحي مكاناً صناعياً أنثأه الأهل فيسعى الثاعر لوصفه وبيان العادة من حيث الفعل الذي يجري

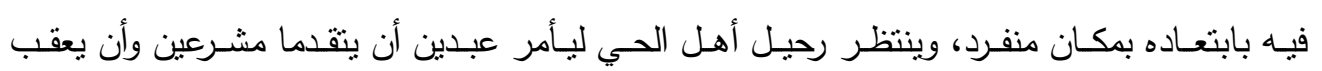


العدد الأربعون

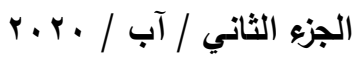

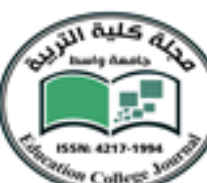

Con colless

طرفيهما حتى لا يرياها، وبذلك يوحي الشـاعر بأجواء الحي، حركة الشخصيات فيه من حيث الفعل الانسـاني الذي يدل على الغيرة والثقاء والغوايـة، ويركز الثـاعر على نقطة الجذب في هذا المكان الصناعي ألا وهي (الجحيش) أي الناحية التي ينفرد بها من حيث الإسـراع والانقياد حتى لا يراه أي أحد من أهل الحي.

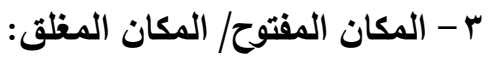
تشكل ثثائية المفتوح والمغلق من طبيعة المكان الذي تحده أو لا تحده الحواجز والحدود والقيود التي تشكل عائقاً لحرية حركات الانسان وفعالياته ونشاطاته وانتقاله من مكان لآخر ، وتحدد من جهة أخرى طبيعة العلاقة مع الآخرين وانفتاح هذه العلاقة أو انغلاقها على قوانين وضوابط وشروط المسموح بها وغير مسموح بتجاوزها(·)، لذا "قليس ثمة فرق بين مكان مغلق إلى منفتح في النص الفرق بينهما من حيث كونهما مكانين مسمين في الطبيعي، أما عن الفنان فقد يكون للمكان المغلق قيمة فنية وجمالية رغم محدودية مساحته، وقد يكون أكثر ضيقاً مما هو عند كاتب ضعيف المخيلة"(VI). ومن أمثلة وصف المكان المفتوح:

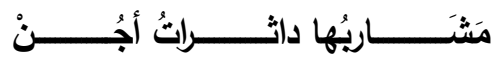

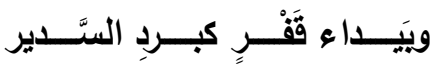

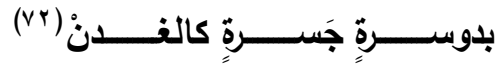

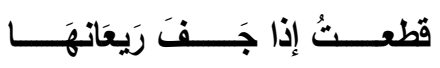

يركز الثـاعر في وصفه للمكان المفتوح على دالة الصحراء التي تمثل هذا النوع من الامكنة خيـر تمثيل فهي متراميـة الأطـراف وقفر ، إذ يشبهـها الثـاعر بدير ارض الـيمن مـن حيث البـرد والثتوب المخطط من شـارب الميـاه التي يشرب منهـا المسافر إذ يوحي بذلك الوصـف إلى تجريدها وركودهـا مطموسة من الآبـار، ومما يدل على انفتاح الصحراء وسعتها توسط الثمس للسماء التي فوقها مـع ظاهرة السراب التي يراها المسافر والاستعداد بذلك السير بناقة ضخمة. ومن نماذج وصف المكان المفتوح:

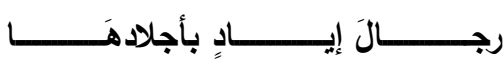

بِ لا تُخطئَــــوا بعـــضَ أرصـــــادِها

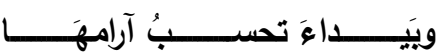

يقــــولُ الــــليلز بهـــــا للصنَّـــا 


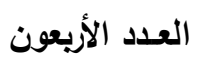

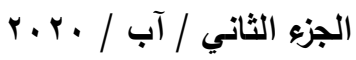

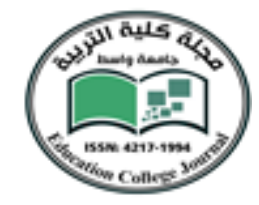

ويعود الثاعر من جديد ليقدم دالات وصفية للصحراء بوصفها مكاناً مفتوحاً أمام السسافر الذي يجدها لا تتنهي أبـاً، إذ تتنصب الحجـارة وسط هذا المكان ليهتدي بها المسـافر إلى الجهة التي يقصدها بالسير فلابد من تتبع هذه الأعلام وألا يتعرض للتيه وسط هذا الفضاء الواسع الممتد، فضلاً عن تحمل مصاعب السير نهاراً من حر الهاجرة حين يرتقع لسراب. ومن أمنلة وصف المكان المغلق:

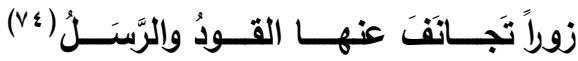

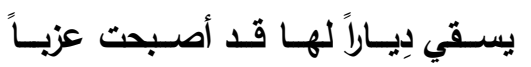

وإذا كان الثـاعر قد قدم دالات وصفية للككان المفتوح ولاسيما الصحراء فهو في نصوص شعرية أخرى يقدم مقاطع وصفية عن المكان المغلق كما في الديار التي يوحي ذكرها بانغلاقها أولاً وبعدها

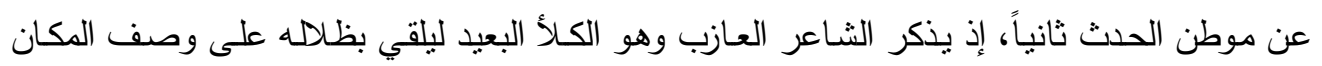
المغلق، لذا ينحرف عنها القود (الخيل) والرسل (الجماعة والقطيع من كل شيء). ومن نماذج وصف المكان المغلق:

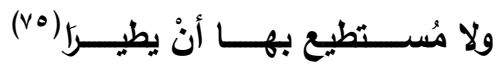

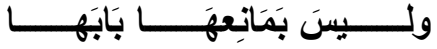

ينتقل الثـاعر إلى وصف آخر للمكان المغلق بدلالة (مانعها باب) إذ يدخل المنع على إيحاء بهذا

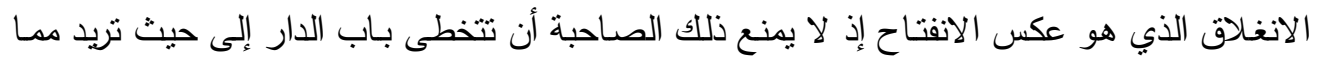
يدل على انغلاقية هذا الدكان على الثخصية الني لا تمارس فعلها في الخروج منه.

\section{الخاتمة}

بعد الانتهاء من دراسة الوصف القصصي في شعر الأعثى الكبير يسجل البحث أبرز النتائج التي توصل إليها على وفق ما بأني: • أبرز الثـاعر البعد الخارجي للشخصية ولاسيما صـاحبته بدالات وصفية من حيث جسمها بشكل

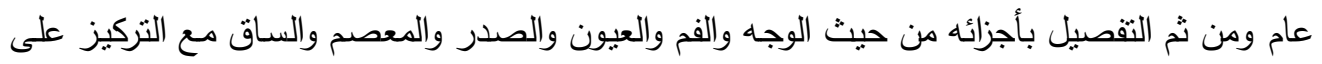
تتاسق الاعضـاء ورطوبة الجسم وعبق رائحته، في حين يعبر بالوصف عن بعده الفكري من حيث

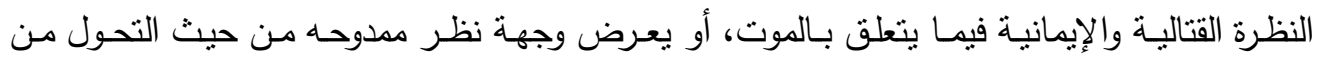


العدد الأربعون

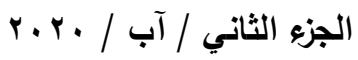

الفساد الى الرشـاد والبعد عن السفه، ويسجل الثاعر دالاته الوصفية للبعد النفسي للثخصية الممدوح وفرسانه والناس من حيث ثيمة الغزو وآثارها في النفس الإنسانية من حالات الفزع والرعب من الحرب وتحمـل مشـاقها وعدم الثـعور بـالأمن والسـلام في حين يبدو وصـف البعد الاجتمـاعي للشخصـية بـالتركيز على دالات اجتماعيـة للممدوح على الثجاعة والاستبسـال في مواجهة العدو ووهب مالـه للفقراء وتعبيره بالقوة والسماحة والكرم والدقة في سياسة الحرب. • اعتمد الثـاعر في الاسـتهلال الوصفي على دالات وصفية مـن حيث ذكر الاطـلال وأثزهـا في النفس والتساؤل وأثر الرياح على الأمكنة، ورحيل الصاحبة ووداعها وعدم الصبر على فراقها ومن ثم وصف خاتمة الحدث الاستباقي لمظاهر رؤينها لينتهي الى وصف حدث القتال وأثز ذلك على النساء والثيوخ والرجال الاغنياء الذين قصدوا أموالهم، مع تقديم أوصاف للأحداث الاستباقية واسنشرافها في المستقبل مع أحداث الحاضر ورواية الحدث الماضي للتعبير عن أوصاف القوم. استتد الثـاعر في الوصف القصصي على دالات متعددة عن الأمكنة بثنائيات متعددة هي المكان الأليف من حيث أمكنة أفعال الممدوح ومن حيث ارتيـاد الثـاعر للحانوت وقضـاء ليلته في شـرب الخمر ، والمكان المعـادي من حيث الصحراء ورهبتها المفزعة وسكونها مما يعبر عن خوف المسـافر ورعبه وشعوره بالوحشة فليس فيها أي شي الا صوت الجن المرعب، ويبرز المكان الطبيعي من حيث الرياض ومكوناتها والثمس فضـلاً عن الأرض المسنتوية والربوة والجبل والانتقال بين الروئية الأفقية والعموديـة مـن حيث الاتخفـاض والعلو للأمكنـة، والمكـان الصـناعي من حيث الحسانوت الذي يسـلزم أدوات العمل من مواقع الجلوس وأدوات الشرب، فضـلاً عن الحي والتركيز على جزئية الجحيش مـن حيث الانفراد والإسـراع والابتعـاد في حين يبدو المكان المفتوح بالصحراء واسعة الأطراف ومتراميـة الأبعاد للمسـافر من أثر نظرة السراب وكأنها لا تتنهي مطلقاً في حين يتحدد المكان المغلق بالديار البعيدة عن موضع الحدث او الثقيد بعدم الخروج منها مما يثبت انغلاقيتها. 
العدد الأربعون

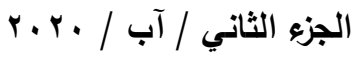

(') قدامة بن جعفر، نقد الشعر، تحقيق: عبد المنعم خفاجي، مكتبة الخانجي، القاهرة، 19 11 11 11. (') أبو هلال العسكري، كتاب الصناعتنن، تحقيق: محمد البجاوي ومحمد أبو الفضل إبراهيم، المكتبة العصرية، صبيدا، .1 $150: 1914$

(") ابن رشيق القيرواني، العمدة في محاسن الثعر وآدابـه ونقده، تحقيق: محمد محيـي الدين عبد الحميد، دار الجيل،

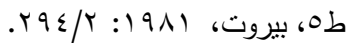
( ) محمد الناصر العجمي، الخطاب الوصفي في الأبب العربي القديم، الثـعر الجاهلي أنموذجاً، مركز نشر الجامعـة،

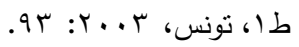

( ) ينظر : إيليا حاوي، فن الوصف وتطوره في الثعر العربي، دار الثرق الجديد، طا، بيروت، 1909 1: 7 ــ. 1.

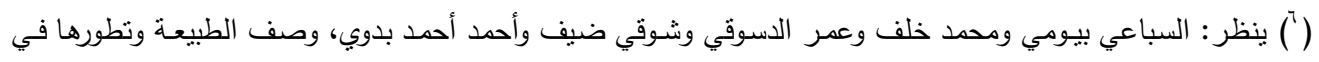
الثعر العربي، مكتبة نهضة مصر، القاهزة، (د. ت): 1.

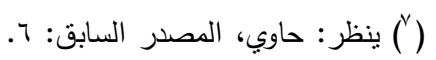

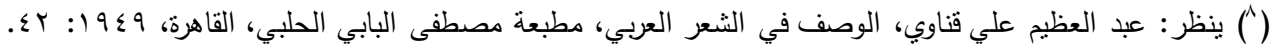

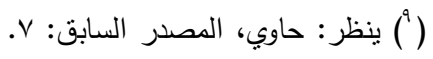

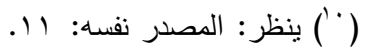

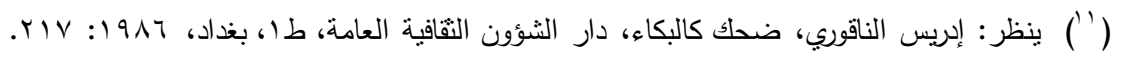

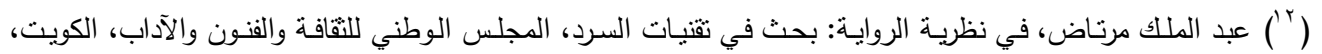
. . ค

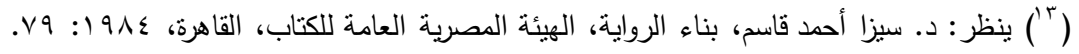

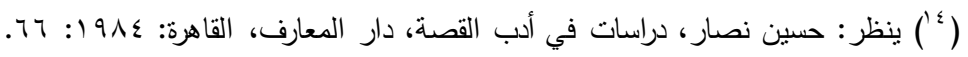

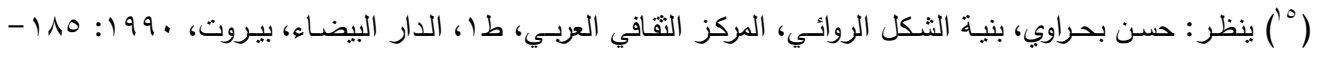

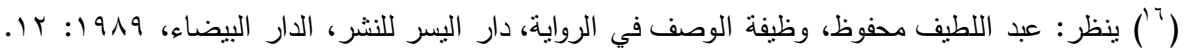

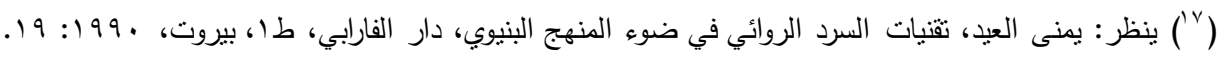

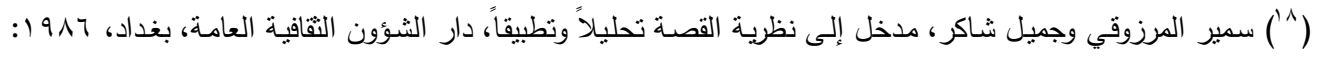

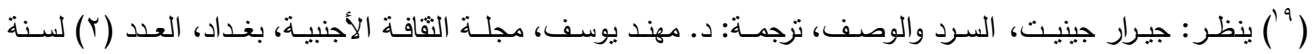
or : $: 1994$

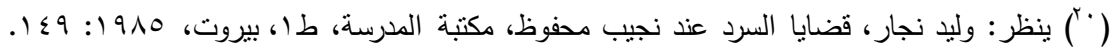


العدد الأربعون

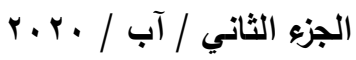

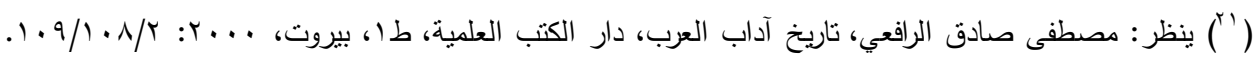

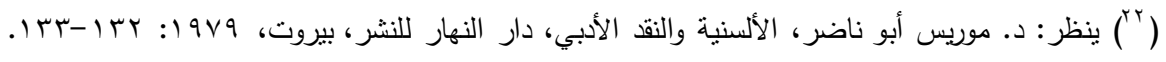

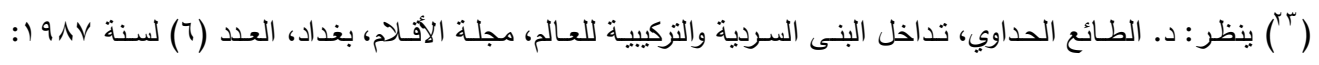

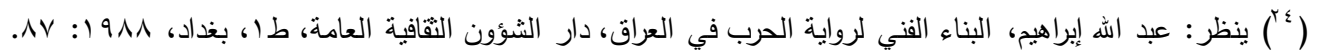

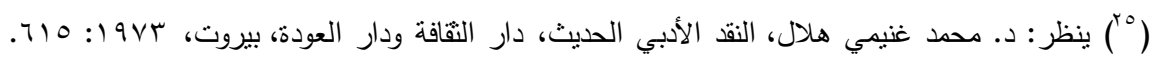

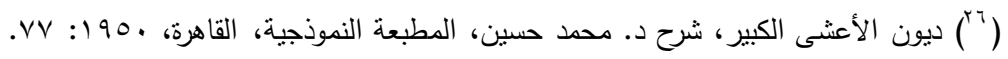

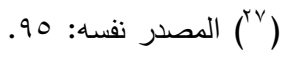

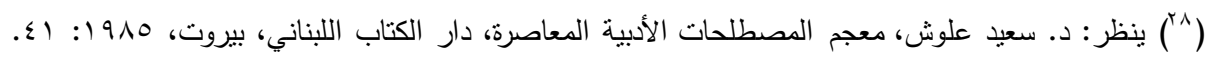

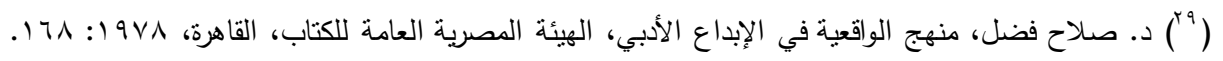

$$
\begin{aligned}
& \text { (") ديوان الأعشى الكبير : بس. } \\
& \text { (') (") المصدر نفسه: } 10 .
\end{aligned}
$$

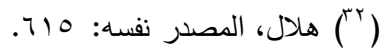

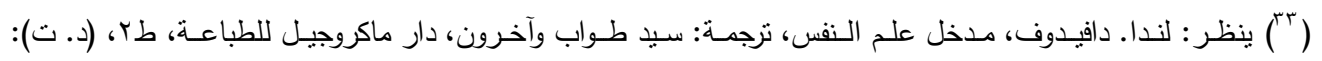

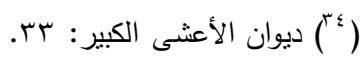

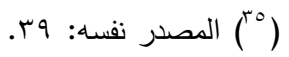

(7) بنظر : فخري صـالح، أرض الاحتمالات من النص المغلق إلى النص المفتوح في السرد العربي المعاصر، المؤسسـة

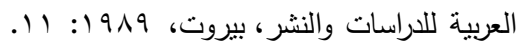

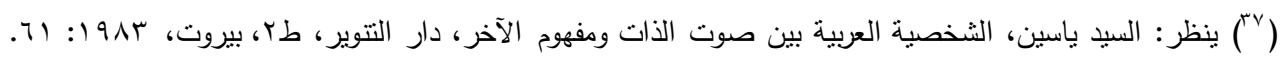

$$
\begin{aligned}
& \text { (1) ديوان الأعشى الكبير : 10. }
\end{aligned}
$$

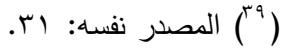

( •) ينظر : د. عبد الملك مرتاض، ألف ليلة وليلة: دراسـة سيميائية وتفكيكية لحكايـة حمـال بغداد، ديسوان المطبوعات

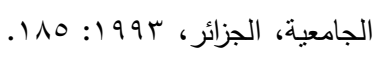

(' (') ينظر : خالد حسين حسين، شـعرية المكان في الروايـة العربيـة الجديدة، الخطاب الروائي لادوار الخراط، مطـابع

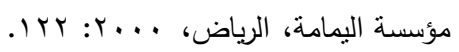

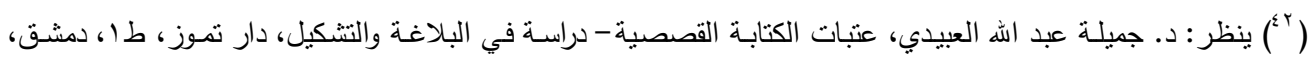


(rاء) د. محمد صـابر عيبد و د. سوسن البياتي، جماليات التتكيل الروائي، دار الحوار للطباعة والنشر والتوزيع،، طا،

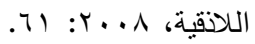

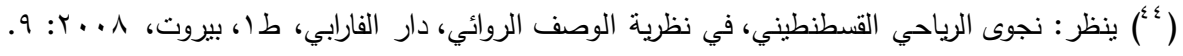

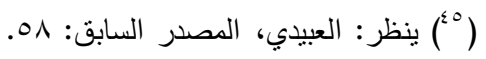

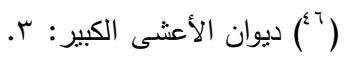
. 00 .

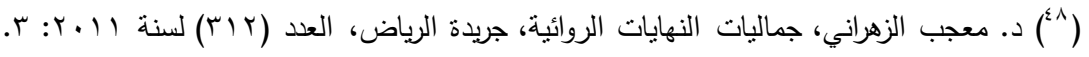

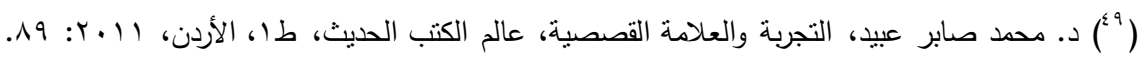

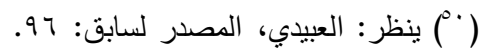

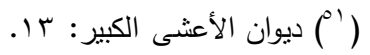

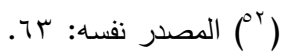

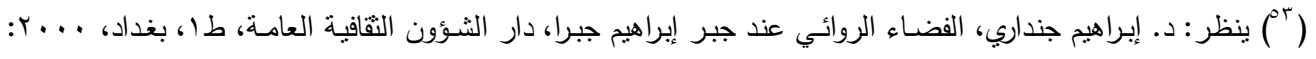

( ) ينظر : د. إبراهيم جنداري، هامشية المكان في روايـة غانم الدباغ ضجة في ذللك الزقاق، مجلة آداب الرافدين، كلية

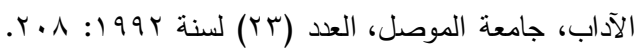

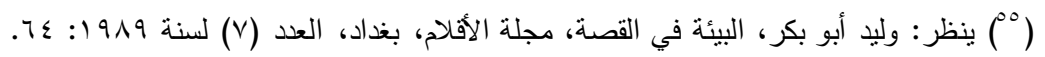

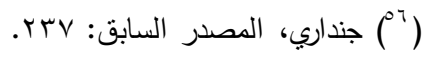

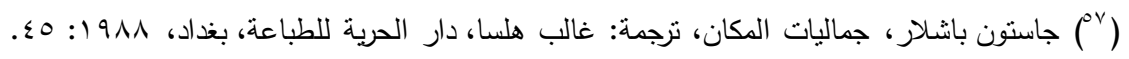

$$
\begin{aligned}
& \text { (1) ديوان الأعشى الكبير : هـ. } \\
& \text { ( ) (199 ) المصدر نفسه: } 79 .
\end{aligned}
$$

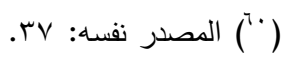

$$
\begin{aligned}
& \text { (") (") المصدر نفسه: (1) }
\end{aligned}
$$

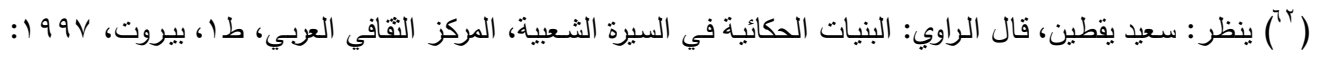

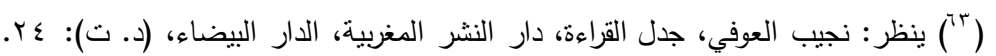

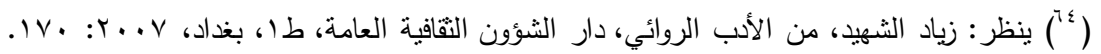

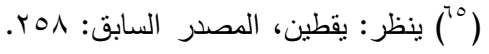

$$
\begin{aligned}
& \text { (") (") ديوان الأعشى الكبير : (1) }
\end{aligned}
$$

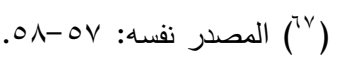




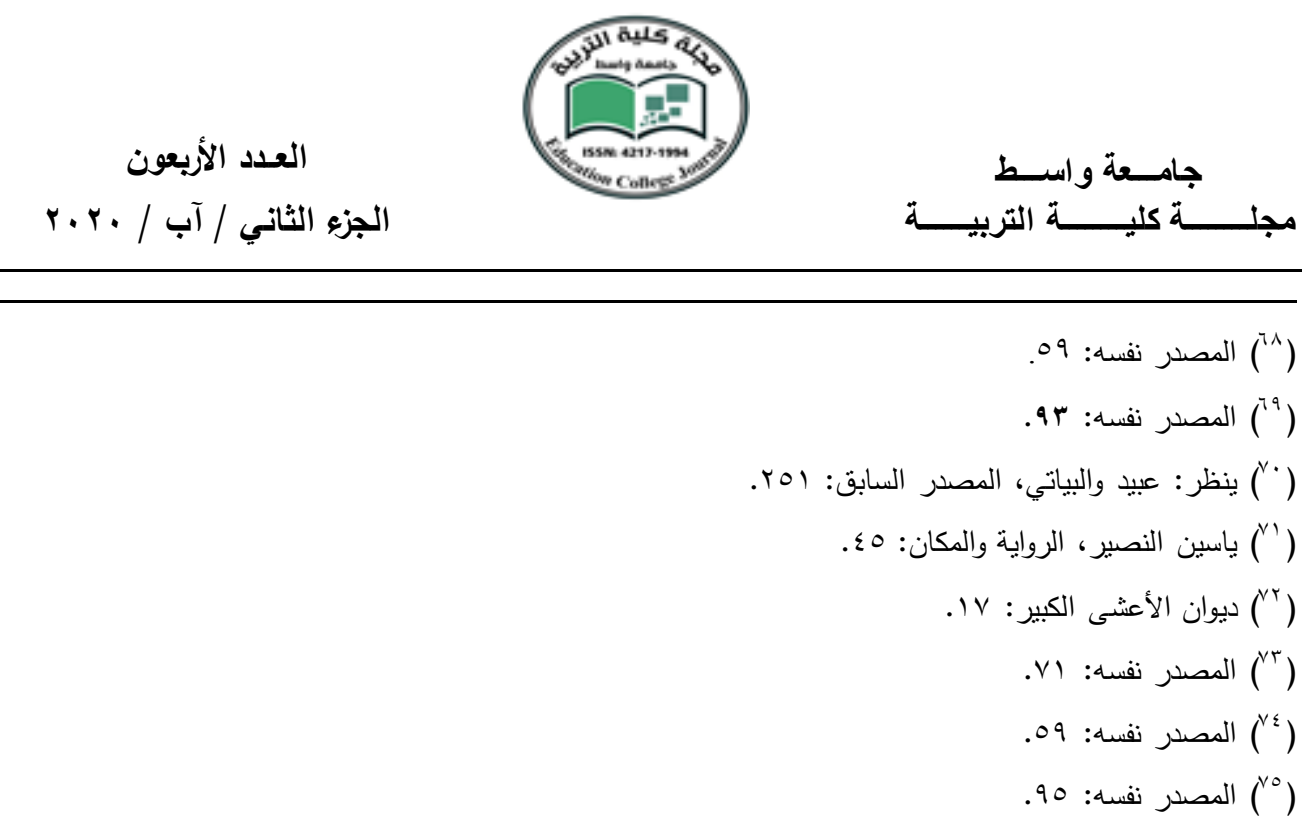

